\title{
A Qualitative Study on Impact of Covid-19 on Mobile Banking Services with Special Reference to the State of Goa.
}

\author{
Ms. Tammana Muzawar \\ Post Graduate Student, Department of Commerce, G.V.M's GGPR College of Commerce \& Economics, \\ Ponda, Goa, India. \\ tamannamuzawar7@gmail.com
}

\begin{abstract}
As we all the entire nation is facing a global Covid-19 pandemic which has nearly affected over 795,605 confirmed cases and 21632 deaths across India. The purpose of the research paper is to re-evaluate the mobile banking services and find the impact. Most of the people in India are directly or indirectly connected with banking services. The lockdown effect has unswervingly deformed into human calamity. The pandemic is an unexpected shock on all the sectors of the economy. This study has been done to determine the socio-economic profile of customers and analyse the major issues in Mobile Banking services. As personal banking is not appropriate during this unusual lockdown stage of Covid-19 pandemic this has forced people to use contactless payments and avoid handling paper money as much as possible. For the purpose questionnaire has been constructed and the data is collected through Google forms surveying 100 customers of mobile banking services in Goa. Results were analyzed using SPSS software and Microsoft Excel and were tabulated using different statistical tools like crosstabulation, bar chart, pie-chart, descriptive analysis using 5 point Likert scale ranging from strongly agree, agree, neutral, disagree and strongly disagree. By using above method and tools the perception of different customers were analysed.
\end{abstract}

Keywords: Covid-19, Pandemic, Mobile Banking Services, Customers, Goa.

\section{Introduction}

The covid-19, corona virus pandemic has affected human beings and various economic sectors globally affecting a large number of populations. Covid-19 has spread globally and impacted on banking services and digital economy. Adding up to this in a report WHO stated that the corona virus is similar to AIDS and therefore it is less expected to be extradited. The pandemic has changed the way in the people around the world in the field of digital banking. Banks have grown up and modernised and came up with technology called mobile banking services that encourage customers for online mode of transactions. Most bank branches encourage customers not to visit their branches and make use of online banking wallets for ongoing day to day transactions. Covid-19 has pushed consumers towards use of online, phone and mobile banking. Covid-19 has turned people to use mobile banking wallets more and more. Mobile banking allows the users to access their accounts, check status online anytime anywhere around the world. It provides services worldwide to customers. Mobile banking wallets are growing day by day and further it is advised by bank advisories to make use of mobile banking applications to secure services, timely update and handle transactions and communication with bank. 
These days due to covid-19 crisis physical handling of cash is risky as there may be chances of getting infected. Customers can use digital payment i.e. mobile banking facility from their homes irrespective of visiting branches. This ultimately limits the use of paper money which is very risky during this pandemic phase. Mobile banking wallets like Google pay, phone pay paytm amazon pay mobikwik, BHIM UPI, SBI yono, freecharge etc. has boosted the banking sector and enhance daily transactions to overcome the barriers of human interactions. The covid-19 crisis has tied with terrific progress in technology; hastened the appearance of all-digital competitor banks across the sphere. Due to sudden shock of pandemic and lockdown most of the people learn how to use mobile banking services and it is no longer an option left and became a mandatory task.

\section{Review of Literature}

Girish, V. (2020) study examines the impact of Covid-19 on Mobile Banking Services. A sample of 80 respondents of Bengaluru city was collected through Google forms. The data was analysed with the help of frequencies, simple percentage, mean, standard deviation and one sample t-test. The study came up with the conclusion that there is impact of Covid-19 on Mobile Banking Services. Gomachab, R. (2018) study is based on impact of Mobile Banking on Customer Satisfaction: Commercial Banks of Namibia (Keetmanshoop). A simple random sampling of 60 respondents with the help of self structured administered questionnaire was used to collect data. The data was analysed using descriptive statistics like modes, means, frequencies further the tables, charts and graphs were analysed with the help of MS Excel software. The study provides evidence that customers of mobile banking services by pointing to mobile services the customers most often use services which are at lower rates and customers are of the opinion that use of mobile banking services are more secure than branch based services. Study, B. A. (2019) study tried to examine Mobile Banking Services and Customer Satisfaction with reference to ICICI Bank. A convenience sample of 50 respondents has been surveyed and the data has been analyzed using percentage and interpreted through tables. The study depicts that ICICI Bank is providing good Mobile Banking Services to its customers.

\subsection{Identification of Research Gap}

The foregoing literature review identified following research gaps: The review of literature has shown that a number of studies have been conducted in the field of Mobile Banking to identify impact of Covid-19 on Mobile Banking Services and Customer Satisfaction. No Concrete Study on Impact of Covid-19 on Mobile Banking Services has been conducted in the State of Goa. From the above review of literature the researcher concentrates on the impact of Mobile Banking on Customer Satisfaction and only study examines the impact of Covid-19 on Mobile Banking Services. However, not much has been researched on on Impact of Covid-19 on Mobile Banking Services has been conducted. Hence, I picked up this particular area for study to find out Impact of Covid-19 on Mobile Banking Services in the State of Goa.

\subsection{Objectives of the Study}

The objectives of this study are to find out of Covid-19 on Mobile Banking Services. Conversely, the objectives are split into the following in a specific manner:

1. To study the socio-economic profile of the customers.

2. To scrutinize the impact of COVID-19 on mobile banking services.

\subsection{Research Methodology}

In order to study the above objectives following research methodology has been designed and executed. The major portion of the present research paper is descriptive in nature having both qualitative and quantitative merits. The study was carried out in Goa and covers the sample of 100 customers from Goa by adopting a convenience sampling method. Period of the study is the period of the survey i.e. June 2020 to July 2020 from various mobile banking users. Online survey was carried out for research work as due to Covid-19 epidemic closure, social distancing and redundant travelling is restricted countrywide. Primary data 
www.rspsciencehub.com

is collected by structuring questionnaire through Google forms and was sent to respondents via. Emails and social media to record responses from respondents. The questionnaire dealt with socioeconomic information of customers like gender, age, education qualification, monthly income, user of mobile banking services and types of mobile banking wallets used by them. Close ended questions were framed to examine the impact of Covid-19 on mobile banking services of which the gathered data was further used for descriptive analysis. The relevant secondary information has been congregated from various reference books, journals, articles, previous research papers, and websites related to mobile banking. The collected data has been analyzed with the help of statistical tools like Reliability Analysis, Cross tabulation, Frequency tabulation, Descriptive analysis, pie chart and bar chart were used. The five Point Likert scales i.e. varying from Strongly Agree to Strongly Disagree has been used to scrutinize the impact of COVID-19 on mobile banking services. By the above methods and tools used, the customer's opinion on various aspects of Mobile Banking during Covid-19 is collected and analysed using SPSS Software version 20.

\subsection{Limitations of the Study}

1. Due to time constraint, only 100 respondents were chosen.

2. The choice of sample has been restricted only to the respondents of Goa.

3. Respondents opinion are vibrant, they keep changing moment in time to time.

4. The study is entirely based on the information precise by mobile banking users and for this reason; there are some chances of getting illusory information as respondents are too sensitive and doesn't disclose correct information for some questions.

\section{Findings and Discussions}

\section{Reliability Test}

Table.1 Reliability Statistics
Volume 02 Issue 07 July 2020

\begin{tabular}{|c|c|}
\hline Cronbach's Alpha & N of Items \\
\hline .684 & 11 \\
\hline
\end{tabular}

Source: Data computed from Primary Source through Questionnaire Method using SPSS

The reliability analysis measures the internal consistency and it was conducted by considering 100 numbers of respondents. The Cronbach's Alpha is used to access the reliability or internal consistency of the data. The reliability of any measurement refers to the extent to which it is a consistent measure of a concept and Cronbach's Alpha is one way of measuring the strength of the consistency. Cronbach's Alpha value should be more than 0.60. And in this case, the Cronbach's Alpha value is 0.684 . It shows that, there are $68.4 \%$ internal consistencies of the scales. Hence, the instrument used in this study has a high reliability value.

\subsection{Socio-Economic Profile}

Objective 1: To study the socio-economic profile of the respondents.

Table. 2 Gender * Age Cross tabulation

\begin{tabular}{|c|c|c|c|c|c|c|}
\hline & \multicolumn{4}{|c|}{ Age } & \multirow{2}{*}{$\begin{array}{c}\text { Tota } \\
1\end{array}$} \\
\hline & & $\begin{array}{c}18- \\
22 \\
\text { yrs }\end{array}$ & $\begin{array}{c}22-27 \\
\text { yrs }\end{array}$ & $\begin{array}{c}28- \\
32 \\
\text { year } \\
\text { s }\end{array}$ & $\begin{array}{c}33 \\
\text { or } \\
\text { mor } \\
\text { e }\end{array}$ & \\
\hline \multirow{2}{*}{ Gender } & Male & 5 & 12 & 25 & 6 & 48 \\
\hline & $\begin{array}{l}\text { Femal } \\
\mathrm{e}\end{array}$ & 3 & 20 & 20 & 9 & 52 \\
\hline \multicolumn{2}{|c|}{ Total } & 8 & 32 & 45 & 15 & 100 \\
\hline
\end{tabular}

Source: Data computed from Primary Source through Questionnaire Method using SPSS

Table No. 2 shows the socio-economic profile of the respondents. Data was collected and crosstabulated in the above tables. It is noted that out of 100 respondents 48 are male and 52 are female. It 
www.rspsciencehub.com

shows that high proportion of females among Mobile Banking users in Goa.

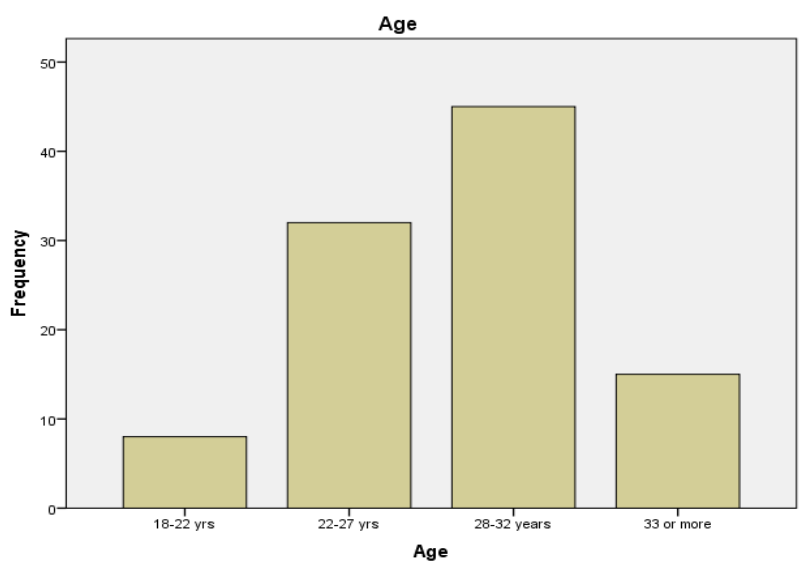

Chart.1. Bar Chart showing age of the respondents

Majority of the respondent's i.e. 45 and 32 respondents come under the age group between 28-32 years and age group between 22-27 years respectively. Very few respondents are coming under the age group between 18-22 years.

Table. 3 Education Qualification * Monthly Income Cross tabulation

\begin{tabular}{|c|c|c|c|c|c|c|}
\hline & & \multicolumn{4}{|c|}{ Monthly Income } & \multirow{2}{*}{$\begin{array}{c}\text { Tota } \\
1\end{array}$} \\
\hline & & $\begin{array}{c}\text { Belo } \\
\text { w } \\
1500 \\
0 \\
\end{array}$ & $\begin{array}{c}1500 \\
0- \\
2500 \\
0 \\
\end{array}$ & $\begin{array}{l}25000- \\
35000\end{array}$ & $\begin{array}{c}\text { Ab } \\
\text { ove } \\
350 \\
00 \\
\end{array}$ & \\
\hline \multirow{5}{*}{$\begin{array}{l}\text { Educa } \\
\text { tion } \\
\text { Qualif } \\
\text { ication }\end{array}$} & SSC & 1 & 2 & 1 & 0 & 4 \\
\hline & HSSC & 0 & 4 & 12 & 3 & 19 \\
\hline & $\begin{array}{r}\text { Gradu } \\
\text { ation }\end{array}$ & 2 & 8 & 21 & 5 & 36 \\
\hline & $\begin{array}{r}\text { Post } \\
\text { Gradu } \\
\text { ation } \\
\end{array}$ & 3 & 15 & 11 & 8 & 37 \\
\hline & $\begin{array}{c}\text { Profes } \\
\text { sional }\end{array}$ & 1 & 1 & 2 & 0 & 4 \\
\hline \multicolumn{2}{|c|}{ Total } & 7 & 30 & 47 & 16 & 100 \\
\hline
\end{tabular}

Source: Data computed from Primary Source through Questionnaire Method using SPSS

Table No. 3 depicts educational qualification and monthly income of the respondents, out of 100
Volume 02 Issue 07 July 2020

respondents, maximum 37 of the respondents are Post graduates and 36 respondents are Graduates and the minority i.e. only 4 respondents appear under SSC and Professional level of education qualification whereas, most of the people come under income group between 25,000-35,000 and very few people come under the income group of below 15000 .

Table 4 Consumers using of Mobile Banking wallets * Are you the user of Mobile Banking Services? Cross tabulation

\begin{tabular}{|c|c|c|c|c|}
\hline & & \multicolumn{2}{|c|}{$\begin{array}{c}\text { Are you the } \\
\text { user of Mobile } \\
\text { Banking } \\
\text { Services? }\end{array}$} & \multirow[t]{2}{*}{ Total } \\
\hline & & Yes & No & \\
\hline \multirow{8}{*}{$\begin{array}{l}\text { Consu } \\
\text { mers } \\
\text { using } \\
\text { of } \\
\text { Mobile } \\
\text { wallets }\end{array}$} & Paytm & 18 & 3 & 21 \\
\hline & Phone Pay & 14 & 1 & 15 \\
\hline & $\begin{array}{r}\text { Google } \\
\text { Pay } \\
\end{array}$ & 26 & 3 & 29 \\
\hline & $\begin{array}{r}\text { Amazon } \\
\text { Pay }\end{array}$ & 10 & 0 & 10 \\
\hline & BHIM & 9 & 0 & 9 \\
\hline & $\begin{array}{r}\text { HDFC } \\
\text { PayZapp }\end{array}$ & 4 & 0 & 4 \\
\hline & SBI Yono & 7 & 0 & 7 \\
\hline & Other & 5 & 0 & 5 \\
\hline \multicolumn{2}{|c|}{ Total } & 93 & 7 & 100 \\
\hline
\end{tabular}

Source: Data computed from Primary Source through Questionnaire Method using SPSS

The above table no. 4 shows the users of Mobile Banking Services. From the table 4 it is concluded out of 100 respondents almost all the respondents i.e. 93\% are using Mobile Banking services. 


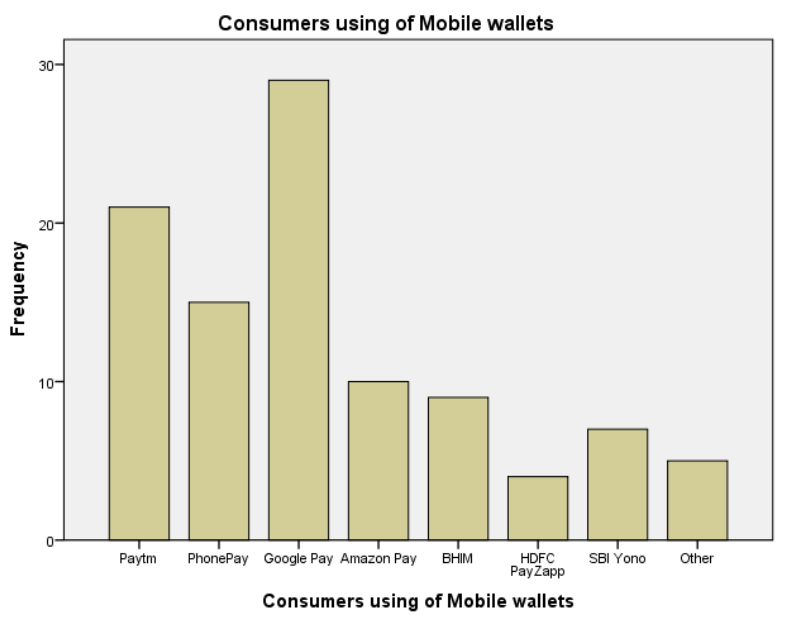

Chart.2. Bar Chart showing consumers usage of Mobile wallets
The Chart.2. depicts mobile banking wallets using by the consumers. Out of 100 customers $29 \%$ of the customers are using Google pay for banking transactions, 21\% customers are using Paytm, $15 \%$ customers are using Phone pay, 9\% use BHIM application, $7 \%$ of them use their conventional banking application and very few i.e. $4 \%$ and $5 \%$ of the mobile banking users use HDFC PayZapp and other applications like Pay pal, Mobikwik, Free charge and ICICI Pockets. From the above graph it is clear that Google pay, Paytm and Phone pay applications were mostly used by the mobile banking customers.

\section{Descriptive Analysis}

Table No. 5 Descriptive statistics showing impact of COVID-19 on Mobile Banking Services

Objective 2: To scrutinize the impact of COVID-19 on mobile banking services.

\begin{tabular}{|c|c|c|c|c|c|}
\hline \multicolumn{6}{|c|}{ Descriptive Statistics } \\
\hline & $\mathbf{N}$ & MIN & MAX & Mean & SD \\
\hline $\begin{array}{l}\text { Expansion in mobile banking services due to Covid-19 } \\
\text { pandemic }\end{array}$ & 100 & 1 & 3 & 1.78 & .543 \\
\hline $\begin{array}{l}\text { Provides } 24 \times 7 \text { hours secure services and easy accessibility } \\
\text { during Covid-19 crisis }\end{array}$ & 100 & 1 & 3 & 1.40 & .603 \\
\hline $\begin{array}{l}\text { Mobile Banking Services are more flexible and convenient } \\
\text { than physical banking during Covid- } 19 \text { pandemic }\end{array}$ & 100 & 1 & 3 & 1.50 & .644 \\
\hline $\begin{array}{l}\text { It provides opportunity for digital banking during Covid- } \\
19 \text { phase }\end{array}$ & 100 & 1 & 3 & 1.46 & .642 \\
\hline $\begin{array}{l}\text { Mobile Banking Services provides contactless payment as } \\
\text { it does not involve handling paper money }\end{array}$ & 100 & 1 & 4 & 1.63 & .646 \\
\hline $\begin{array}{l}\text { Timely update and maintenance of records due to Covid- } \\
19 \text { crisis }\end{array}$ & 100 & 1 & 4 & 1.94 & .874 \\
\hline $\begin{array}{l}\text { Factor-Better problem handling capability than } \\
\text { conventional banking }\end{array}$ & 100 & 1 & 5 & 2.96 & 1.317 \\
\hline $\begin{array}{l}\text { Mobile Banking Payments provides opportunity to earn } \\
\text { rewards, cash backs and coupons }\end{array}$ & 100 & 1 & 5 & 3.23 & 1.294 \\
\hline $\begin{array}{l}\text { Time saving, cost effective, reliable and easy to use than } \\
\text { Conventional Banking }\end{array}$ & 100 & 1 & 4 & 1.98 & .804 \\
\hline Services are compatible with mobile banking & 100 & 1 & 5 & 2.82 & 1.351 \\
\hline $\begin{array}{l}\text { Mobile Banking has fulfilled my expectations than } \\
\text { Conventional Banking during Corona virus pandemic }\end{array}$ & 100 & 1 & 3 & 1.56 & .574 \\
\hline Valid N (listwise) & 100 & & & & \\
\hline
\end{tabular}

Source: Data computed from Primary Source through Questionnaire Method using SPSS 
A descriptive statistic is a summary that quantitatively describes or abridges features from a collection of data, while descriptive statistics is a process of using and examining those statistics. The table is a tool which is used to obtain quick summaries of numeric variables, or to compare several numeric variables side-by-side. The above table shows descriptive statistics on showing impact of COVID-19 on Mobile Banking Services in the state of Goa. The minimum and maximum count observed on various opinions of customers regarding Mobile Banking during Covid-19 pandemic is 1 and 5 which indicates strongly disagree and strongly agree respectively. Mean value calculates the averages for the variables. From the above table it is noted that mean value obtained mostly for all the variables is less than 2 from the average of 5 point rating Likert scale which indeed means customers outlook are moving from agree to strongly agree in the estimation of the mobile banking services.

Provides $24 \times 7$ hours secure services and easy accessibility during Covid-19 crisis has the lowest mean (average) value of other 10 variables and the value is 1.40 and Mobile Banking Payments provides opportunity to earn rewards, cash backs and coupons has the highest average of 3.23. The mean value of services is compatible with mobile banking and better problem handling capability than conventional banking is 2.82 and 2.96 respectively. Services are compatible with mobile banking and better problem handling capability than conventional banking has the highest standard deviation of 1.351 and 1.317 which explains variance.

From the study, it is cleared that since Time saving, cost effective, reliable and easy to use than Conventional Banking, timely update and maintenance of records due to Covid-19 crisis, expansion in mobile banking services due to Covid-19 pandemic, Mobile Banking Services provides contactless payment as it does not involve handling paper money, Mobile Banking has fulfilled my expectations than Conventional Banking during Corona virus pandemic, Mobile Banking Services are more flexible and convenient than physical banking during Covid19 pandemic and it provides opportunity for digital banking during Covid-19 phase which has the mean value above 2 i.e. $1.98,1.94,1.78,1.63$, $1.56,1.50$ and 1.46 respectively for all this variables Hence it can be inferred that there is impact of COVID-19 on mobile banking services and due to COVID-19 there has increased using of mobile banking services.

\section{Findings of the study}

In this paper, the focus is on the impact of Covid19 on Mobile Banking. Therefore, before doing factor analysis, Reliability analysis has been done. It is found that the Cronbach's Alpha value is obtained as 0.684 that shows, there are internal consistencies of scales. Hence, the instrument used in this study has a satisfactory reliability value. It is observed that out of 100 respondents 48 are male and 52 are female. The majority of the respondent's i.e. 45 and 32 respondents come under the age group between 28-32 years and age group between 22-27 years. Very few respondents are coming under the age group of between 18-22 years. It is noted that, majority i.e. 37 of the respondents are Post graduates and 36 respondents are Graduates and the minority i.e. only 4 respondents appear under SSC and Professional level of education qualification whereas, most of the people come under income group between 25,000-35,000 and very few people come under the income group of below 15000. Further it is revealed that, out of 100 respondents almost all the respondents i.e. $93 \%$ are using Mobile Banking services and from that Google pay, Paytm and Phone pay applications were mostly used by the mobile banking customers. From descriptive statistics it is noted that mean value obtained mostly for all the variables is less than 2 from the average of 5 point rating Likert scale which indeed means customers outlook are moving from agree to strongly agree in the estimation of the mobile banking services.

\section{Conclusions}

For the purpose of study, sample of 100 customers of mobile banking from Goa was chosen. Going through survey in the phase of Covid-19 pandemic the main problem with the customers is availability of banking services and 


\section{www.rspsciencehub.com}

assessment of banking services have become more essential. Thus due to covid-19 pandemic and nationwide closure people believe that visiting branches and availing banking services is not safe. As the banks have modernized they have encouraged customers to avail benefit of online, phone and mobile banking services as all these services are available at finger tips of customers in lieu of branch visits. As the time changed people have started accepting mobile banking services for daily transactions and in this crucial phase unnecessary interactions, maintaining social distancing is utmost important so it has put people in situation on how to impend daily tasks. The only way and best option left with the customers for managing money and transact through use of mobile banking and stay safe from deadly virus. The present study has been conducted to find the impact of Covid-19 on Mobile Banking and the study revealed that most of the people are using mobile banking services as it is cleared that since Time saving, cost effective, reliable and easy to use than Conventional Banking, timely update and maintenance of records due to Covid-19 crisis, provides contactless payment as it does not involve handling paper money, Mobile Banking has fulfilled my expectations than Conventional Banking during Corona virus pandemic and are more flexible and convenient than physical banking during Covid-19 pandemic and it provides opportunity for all these variables people agrees and strongly agrees so it is concluded that there is impact of Covid-19 on Mobile Banking and further there is expansion in mobile banking services due to Covid-19 pandemic.

\section{References}

\section{Journals}

[1] Girish, V. (2020). “ Impact of COVID 19 on Mobile Banking Services .” 70, 2790-2797.

[2] Gomachab, R. (2018). THE IMPACT OF

MOBILE BANKING ON CUSTOMER

SATISFACTION : COMMERCIAL BANKS OF NAMIBIA. 23(2).
Volume 02 Issue 07 July 2020

[3] Study, B. A. (2019). Mobile Banking Services and Customer satisfaction with reference to ICICI Mobile Banking Services and Customer Satisfaction with Reference to ICICI Bank - A Study. April. https://doi.org/10.34293/commerce.v7i2.3 45

\section{Book}

[4] On, C., Global, T., \& Worldwide, O. S. (n.d.). And Other Sectors Worldwide IMPACT OF COVID-19. 